Historic, Archive Document

Do not assume content reflects current scientific knowledge, policies, or practices. 
. 


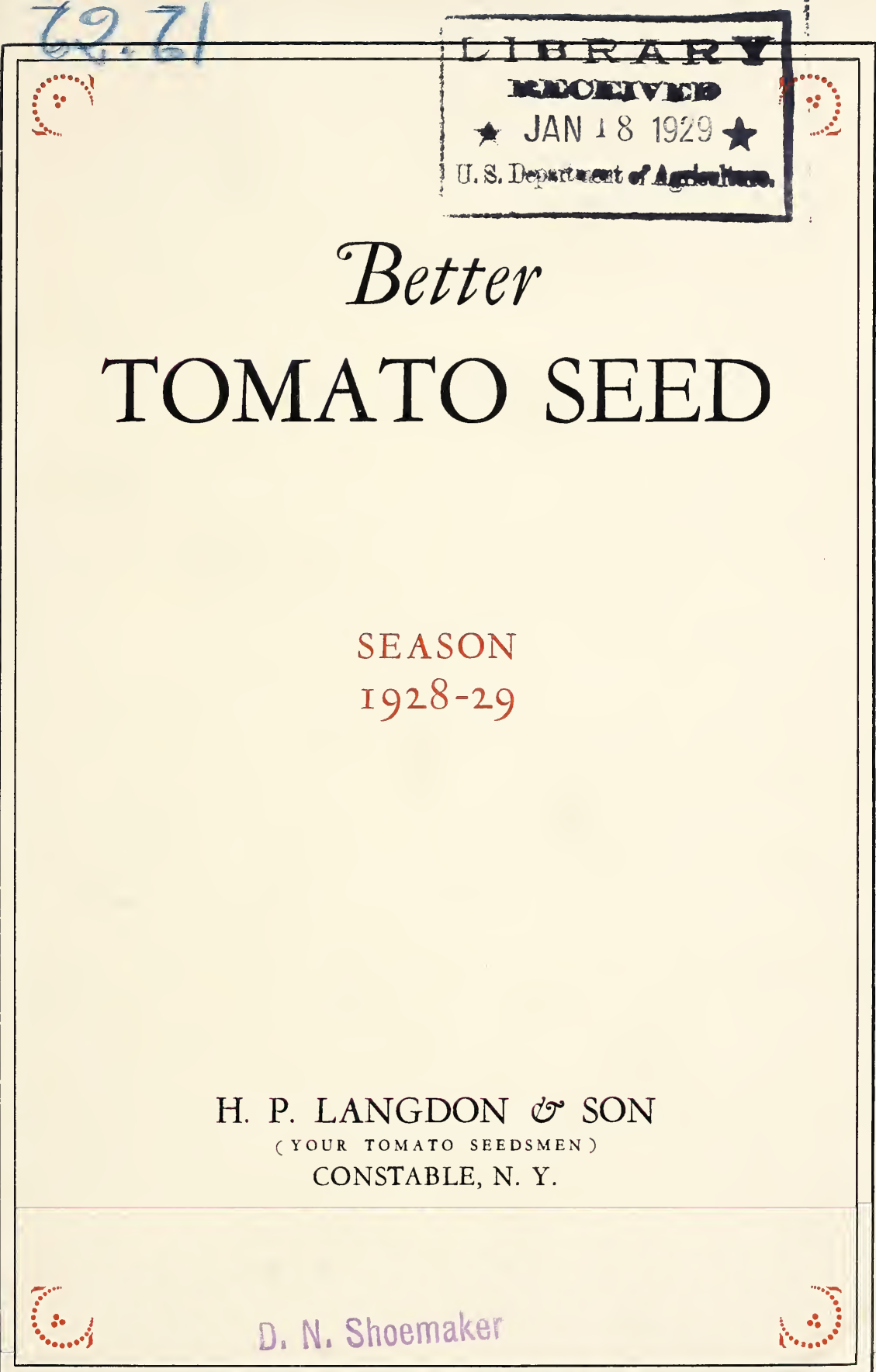





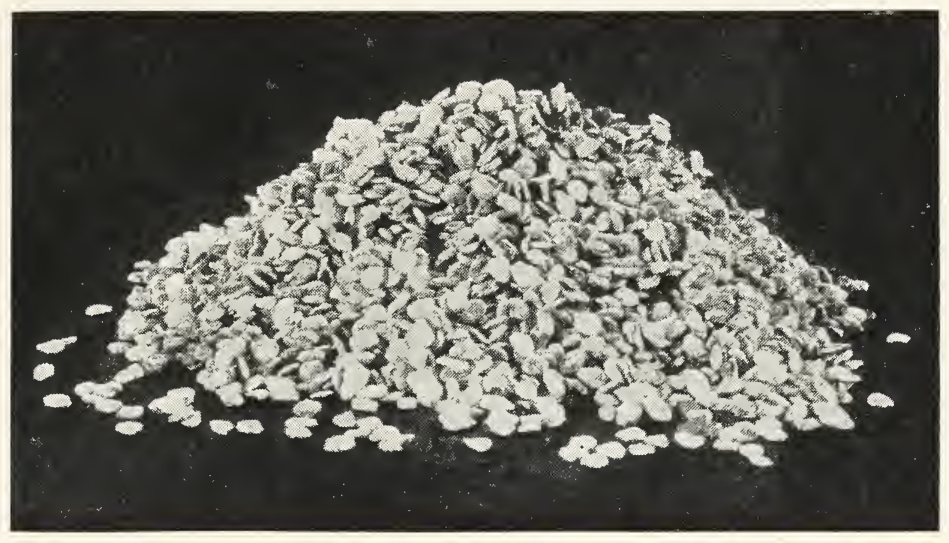

\section{ONE OUNCE OF TOMATO SEED}

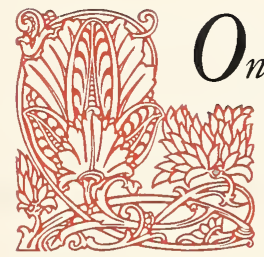

nly a bandful_yet it has more than four thousand seeds. Each seed will be a "Chip of the old block." The factors of variety, earliness, quality and prolificacy that will make or lose your profit are already determined -now, before the seed is even sown. 


\section{This Tomato Seed}

Is grown for you in the way you would grow it for yourself -if you could afford it.

If you were to select your own tomato seed, how would you do it?

"Well," you'd probably say, "One has to know first just what he wants."

That is true. An Earliana plant with a wonderful crop, but a few days late, is not worth much for seed, is it? Neither is an extra early plant of Bonney Best, if for earliness it has sacrificed in yield and quality.

So you would first consider the season of each variety, and in connection with this, the purpose.

You would have an ideal in your mind in choosing the plant type. It must be prolific, of course, with a high percentage of marketable fruit; vigorous, with neither too much nor too little vine; disease resistant.

All these things and many others you would consider, if you were saving your own seed.

Can we, your tomato seedsmen, do more than this? We know tomatoes, of course. Our fields can be left until fully ripe before selecting. We have a power drier that, without regard for sun or rain, results in the strongest germination, and which by removing the hairy fuzz makes the seed easier to sow. We are located in the extreme north (northeastern New York) where vigor and stamina must be bred into a tomato if it is to mature a crop.

The outstanding advantage, however, is this: When you select an extra good plant, you can't tell whether or not it will transmit those good qualities through its seed. Chances are that it will not. So you would have to plant that seed in a plot by itself next year and prove it out-so far as a single year would prove it. If you select ten hills to a variety and you grow, say, five kinds, you must carry on fifty trial plots, to say nothing of a few trials of new varieties.

For a few ounces of seed this, naturally, wouldn't pay you. But for hundreds of pounds of seed, going to several thousand enthusiastic gardeners, we can do just this. 


\section{Line Bred Stock}

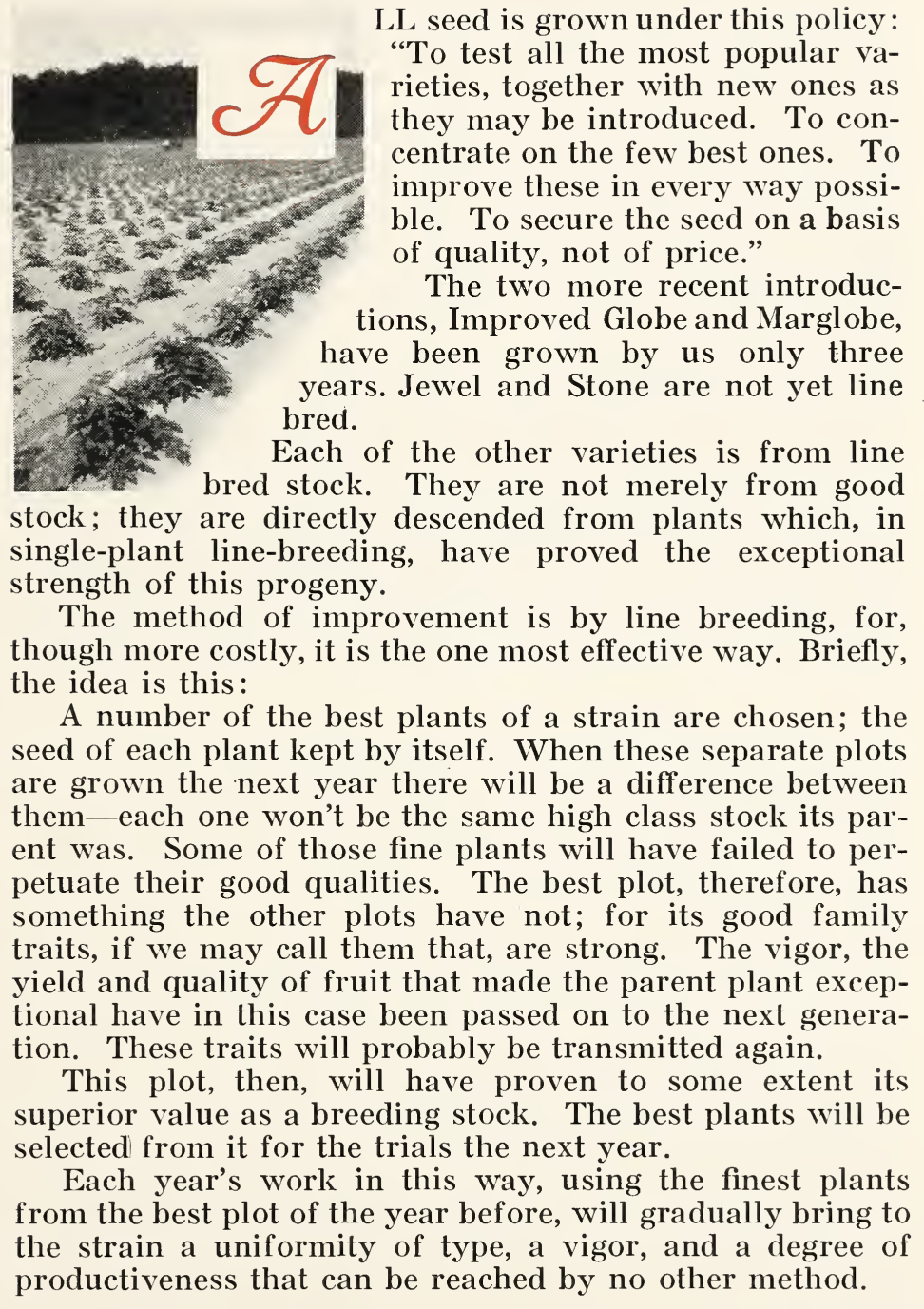

[ Page Three ] 


\section{ADIRONDACK EARLIANA}

(120 days, red)

The Adirondack Strain of Earliana has had twenty-three generations of breeding toward one ideal-extra early fruit of real market quality.

It is extra early; the earliest market variety of which we know. The fruit has given up much of the cussedness of the old type Earliana; it is smooth, quite deep, and firm. Seed cells are small and with thick walls. The color is a good hearty red extending, for an Earliana, remarkably well back toward the stem. The vines, though compact, are vigorous and prolific.

While the Earliana variety has its limitations, as has the extremely early type of any fruit, an improved strain such as this can make you money. Over most of the country the demand is strong-and the price high-for the first home grown tomatoes.

Getting first on the market is partly in knowing how, and then using that knowledge. Start, of course, with seed that will appreciate what you do for it. Read all you can about growing tomatoes. Experiment in a small way with the methods of other folks; perhaps you can adopt some of them to advantage.

The idea that the use of acid phosphate tends to hasten maturity is more than a theory; it is a fact that has been demonstrated over and over. Technical Bulletin No. 28 from New Hampshire gives some interesting results from a number of field tests along this line.

Because the first early plants are well advanced in maturity when set in the field, therefore easily checked, and because the ground is yet cool and with little available nitrogen, the use of nitrate water when setting is of especial benefit to this early crop. Read over the suggestions on page fifteen and try it out next year.

Plan your sowing schedule so that you may have stocky, vigorous plants ready to blossom when setting time comes. And give them room, right from the seed bed. A soft, spindling plant may mature a crop of sorts, but the real tomatoes come on plants which have had a chance to properly develop. This is especially true with extra early varieties. 


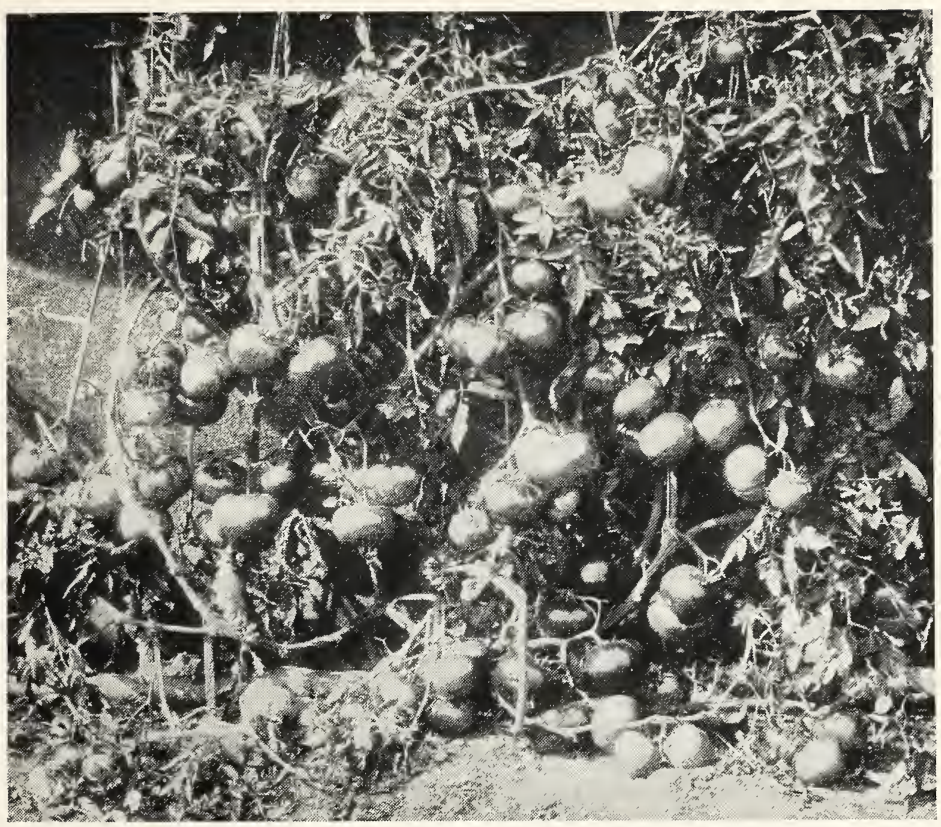

\section{A Fine Type of Extra Early Fruit ADIRONDACK EARLIANA}

NORTH CAROLINA-

Jan. 17, 1928-I have had unusually good success with your Earliana Tomato.

ONTARIO--

April 7, 1928-I find it the best that can be bought.

$\mathrm{OHIO}$

Feb. 10, 1928-We have ordered these from you for some time, and have never seen the equal of this variety.

OKLAHOMA-

Jan. 8, 1928-I have had unusual success with your Earliana in this section, where we have to have them early or not at all.

SOUTH CAROLINA

Jan. 10, 1928-I was more than pleased. I had practically no competition in the early market.

NEW YORK-

March 1, 1928-I found it to be the best seed and the best tomato I've ever had. 


\section{BONNY BEST (Langdon Strain)}

(126 days, red)

The improvement shown by this strain the past few years has been a source of much satisfaction to us, as well as of profit to our customers.

It has gained in earliness, yet retained its heavy yield. More - it has increased in yield. Several tests alongside other strains have given it first place in earliness, and usually first place in total crop as well. That means something, for Bonny Best has always been early enough for good money and noted as a heavy cropper.

The fruit qualities are fine. It picks uniformly a good packing size, a little larger than Bonny Best used to be. The old tendency toward cracking of the skin has largely been overcome. Smooth, round, well colored, firm-it is in every way an excellent packing tomato.

Unless you are seriously troubled by wilt you can use this strain of Bonny Best for second early with every confidence. It is just naturally the best.

If you have extra early soil give this strain a trial as first early. It will ripen a little behind the Adirondack Earliana, but the heavier yield may more than make up. If you have a piece of ground that is especially fertile, yet early and warm, try a few extra early plants pruned to one stem and staked. Pruning will hasten maturity by several days, on rich soil; you may want to go into it on a larger scale another year. Many growers are finding it profitable.

For canning crop the Bonny Best has been very popular. It is now being challenged by the Marglobe, however, even where wilt resistance need not be considered. The Marglobe, a little later in maturing, may produce a slightly heavier crop. It will require several extra pickings for the same bulk, though, for its ripening is delayed over quite a long picking season.

Marglobe has been advised to replace Bonny Best for greenhouse work. Where wilt is a factor Marglobe, being resistant, probably is better. If wilt is not troublesome Marglobe cannot, in our opinion, compete with this strain of Bonny Best in the greenhouse.

[ PAGE SiX ] 


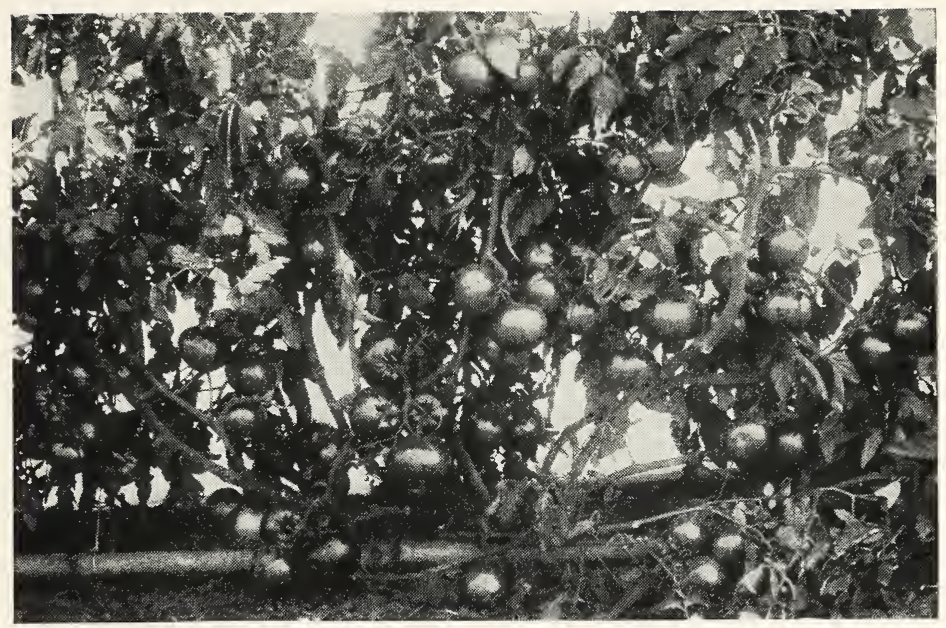

The Best Second Early BONNY BEST (Langdon Strain)

\section{VERMONT-}

Feb. 24, 1928-Your Bonny is surely the best tomato for general purposes that I have ever tried. I use it for first early on account of its better quality, larger vield, and greater disease resistance.

\section{KANSAS-}

Feb. 14, 1928-After experimenting with an ounce of the best tomato seed from several of the leading seed houses last year (yours included) I'm sending for eight ounces of your extra selected Bonny Best.

\section{NEW HAMPSHIRE-}

Feb. 23, 1928-I have been using your seed for a number of years and have always found it to be the best that I could buy as to earliness and productiveness, shape and quality. It is $O$. K. in every respect.

\section{NEW YORK--}

Feb. 15, 1928--I have been growing tomatoes for the past fifteen years and have had seed from nearly every reliable seed house in the east, but have yet to find a Bonny Best that can come anywhere near yours for earliness or productiveness, and as to size it is way ahead of any I have ever grown. 


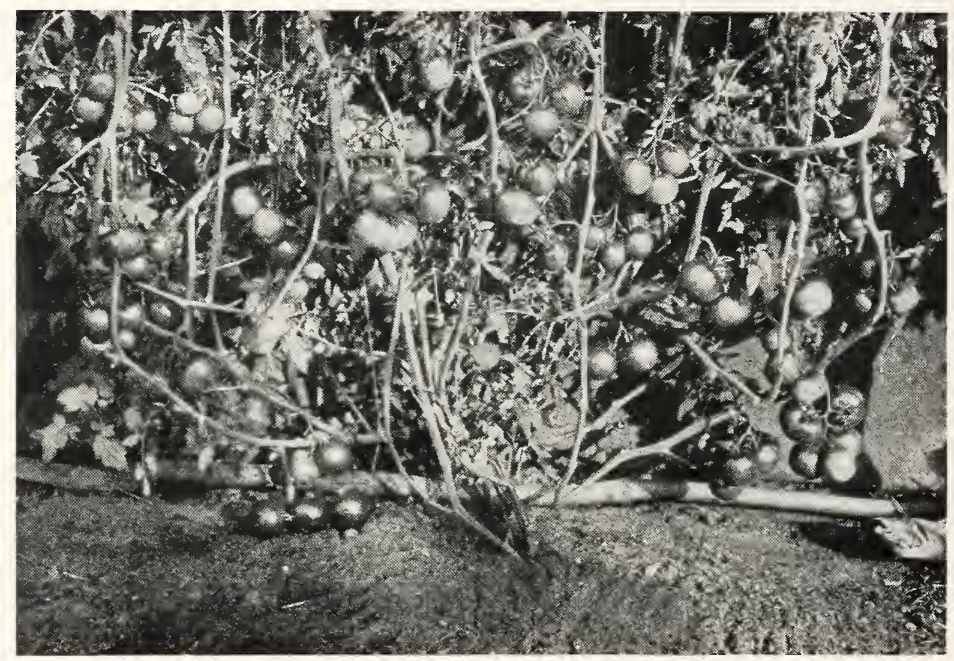

Deep, Smooth Fruit-and Plenty of It

\section{IMPROVED GLOBE}

(138 days, pink)

This improved strain of Globe was introduced by Landreth a couple of years ago, at five dollars an ounce.

A wilt resistance greater than that usually shown by Globe is claimed for this strain by the introducer. We cannot add to this claim with authority, for we have no wilt here and reports from other sections are not yet conclusive.

The increase in earliness shown by this strain is considerable. Its immense productiveness; the deep globe shape of the fruit, with its tough skin free from cracks, blemishes or hard rind; the freedom from cavity at the stem end; the excellent keeping, shipping and table quality - these are all worthy of special mention. Another point is the strong adherence of the ripened fruit to the vine, insuring a firm, live fruit.

Everything considered, this Improved Globe gives promise of being a very worthy strain of a most popular trucking tomato.

[ Page Eight ] 


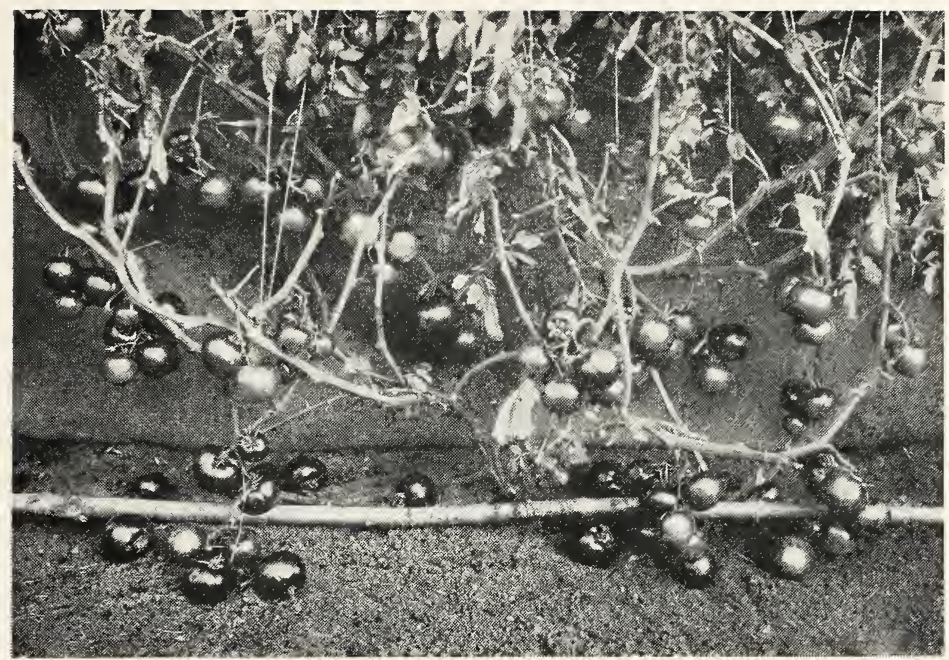

Resistant to Wilt and Nailhead Rust

\section{MARGLOBE}

(142 days, red)

This recent introduction by Mr. F. J. Pritchard, of the Bureau of Plant Industry at Washington, has attracted much attention from all over the country.

It is a midseason variety of strong, though not excessive, vine growth, and matures a heavy crop. The fruit is distinctly globe shaped and a very attractive red in color. There is no depression at the stem end, no hard rind, and very little tendency toward cracking. It is an excellent shipper; its splendid table quality also commends it.

Marglobe is strongly resistant to Fusarium Wilt and to Nailhead Rust, two of the worst diseases which a tomato grower must combat. In the areas subject to infection they can be controlled only by the planting of resistant varieties. And the welcome given Marglobe-Florida changed over half her planting from Globe to Marglobe in two years time, wilt infected areas everywhere are turning to it more and more-such a welcome labels this as one of the most important introductions yet given the tomato grower. 


\section{REDHEAD}

(126 days, red)

An interesting development of this variety was shown in the trial plots of 1926. A plot from seed of 1923, of strong germination, had been included for comparison. The plots from later seed were surprisingly better-they were one week earlier; equally vigorous, yet with a more compact, less-sprawling growth; more prolific. It is seldom that such a change can be noted in three years time.

These improvements bring Redhead pretty well up to Bonny Best in value for second early. These two varieties are much alike, any preference is largely a personal one. We like Bonny Best. However, both are immensely popular -and worthy of it.

\section{BAER}

(128 days, red)

A good choice on dry, light soils, as it will set less fruit but mature them larger than Redhead or Bonny Best will do there. It is a thoroughly dependable variety, but a couple of days later in ripening and possibly not quite so productive as Bonny Best on the better soils.

\section{JEWEL and STONE \\ (132-135 days, red)}

These are old, reliable varieties, well known and quite widely used for early midseason. Jewel has the larger vines and fruit of the two, Stone being somewhat more compact and with fruit about the size of Bonny Best. This is well colored and very firm, a desirable characteristic.

\section{BLOOMSDALE}

(138 days, red)

A high yield of large, well colored and excellently shaped fruit is an outstanding feature of this variety. It surely can fill up the baskets, and, with the exception of a slight tendency to crack in wet weather, the quality is all that could be desired. 


\section{REDROCK}

If you have loss from softening and cracking of midseason and late varieties, give this one a trial. It has a more firm fruit and thicker skin than any other variety we know.

The fruit is not as deep through as would be ideal, nor is it especially uniform in size, but these faults are far overbalanced by the great vigor and heavy yield of the vines and by the deep red color and splendid table and shipping quality of the fruit. For a late midseason crop of special firmness, or for an extra late crop to mature after the first frosts the Red Rock is hard to beat.

\section{Selected Sale Seed}

The policy of listing only the most important commercial varieties is of help both to us and to you-to us because by this concentration we may bring each one to its highest development; to you because you can order any variety listed with confidence that, for its purpose, it is one you can depend on.

Your seed is grown from the finest stock in the line breeding plots. The young plants are rogued at transplanting for vigor, and in the field for purity of type. In gathering the crop only medium to large smooth fruit are taken for seed. The plant, however, and not the individual fruit is used as the basis of selection. Seed is taken from only those plants high in vigor, yield and quality, as well as in the other desirable characteristics of that variety.

The ripe fruit is ground promptly; the pulp washed out at just the right stage of fermentation. Two hours revolving in a drum of 12 mesh screen under blast of air at 100 degrees (120 is safe) dries the seed and thoroughly screens it; then it is spread in trays to cure. About one pound out of forty is again screened away by the fanning mill, leaving plump, vigorous seed. Any seed unsold after eighteen months is discarded-only fresh seed will be sold.

Orders are filled postpaid within twenty-four hours, delivery guaranteed. 


\section{Price of Langdon's Twenty-three Year Selection and Line Bred}

\section{ADIRONDACK EARLIANA}

No. 1 -Run of the field. $1 / 4$ Oz., 25c; $1 / 2 \mathrm{Oz}, 40 \mathrm{c} ; 1 \mathrm{Oz} ., 60 \mathrm{c} ; 2 \mathrm{Oz}$., $\$ 1.20 ; 4$ Oz., $\$ 2.00 ; 8 \mathrm{Oz}$., $\$ 3.60 ; 1$ pound, $\$ 6.40$.

No. 2-Double selection, by vine and fruit. 1/8 Oz., 30c; 1/4 Oz., 50c; $1 / 2$ Oz., 75c. Less than one-half pound, $\$ 1.25$ per Oz.; $1 / 2$ pound, $\$ 9.50$; one pound, $\$ 18.00$.

No. 3-Triple selection, by vine, fruit and interior. Our best. 1/8 Oz., $\$ 1.00 ; 1 / 4$ Oz., $\$ 2.00 ; 1 / 2$ Oz., $\$ 3.00 ; 1$ Oz., \$5.00; 4 Oz., \$18.00. No discount for less than four ounces.

Particular care is given the selection of this No. 3 Earliana. Earliness is of prime importance. Productiveness and vigor are essential. The quality of the fruit must have rigid inspection. After the selection of plant and fruit by outward appearance each fruit is cut individually, by hand, for inspection of the interior construction. A good market tomato will have few seeds and small cells, thick walls, no green or pithy core, will be well colored. Only those fruits showing a high standard of perfection in this, as well as in plant type, are used in the selection of this No. 3 Earliana.

The location at which this seed is grown is worthy of consideration. We are north of the Adirondacks, four miles from the Canadian Line, with a growing season of only about three months and a half free from frost, with generally cool days and many cold nights. This has without doubt been a factor in the improvement of these strains.

OUR WIRRANTY All seed offered by us has been tested and proven to be of good germination. We will replace free of charge any seed which does not germinate under favorable conditions, providing our stock has not been sold out. Naturally, we can go no further than this in guaranteeing your success.

[ Page Twelve] 


\section{LATER VARIETIES}

BONNY BEST, Langdon strain (extra selected) .......... 1/4 oz. 1/2 oz. $1 \mathrm{oz}, 2 \mathrm{oz} .4 \mathrm{oz} .8 \mathrm{oz}$. $\begin{array}{llllll}\$ 1.00 & \$ 1.50 & \$ 2.50 & \$ 4.50 & \$ 8.00 & \$ 14.00\end{array}$ BONNY BEST, Langdon strain (selected) $\ldots \ldots \ldots \ldots \ldots$

REDHEAD (selected) ........

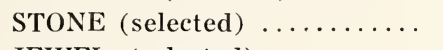

JEWEL (selected) $\ldots \ldots \ldots \ldots$

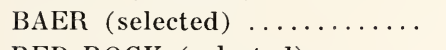

RED ROCK (selected) ........

BLOOMSDALE (selected) ....

GLOBE $\ldots \ldots \ldots \ldots \ldots \ldots$

MARGLOBE

\begin{tabular}{|c|c|c|c|c|c|}
\hline .50 & .75 & 1.25 & 2.25 & 4.00 & 7.00 \\
\hline .50 & .75 & 1.25 & 2.25 & 4.00 & 7.00 \\
\hline .50 & .75 & 1.25 & 2.25 & 4.00 & 7.00 \\
\hline .50 & .75 & 1.25 & 2.25 & 4.00 & 7.00 \\
\hline .50 & .75 & 1.25 & 2.25 & 4.00 & 7.00 \\
\hline .50 & .75 & 1.25 & 2.25 & 4.00 & 7.00 \\
\hline .50 & .75 & 1.25 & 2.25 & 4.00 & 7.00 \\
\hline .50 & .75 & 1.25 & 2.25 & 4.00 & 7.00 \\
\hline .50 & .75 & 1.25 & 2.25 & 4.00 & 7.00 \\
\hline
\end{tabular}

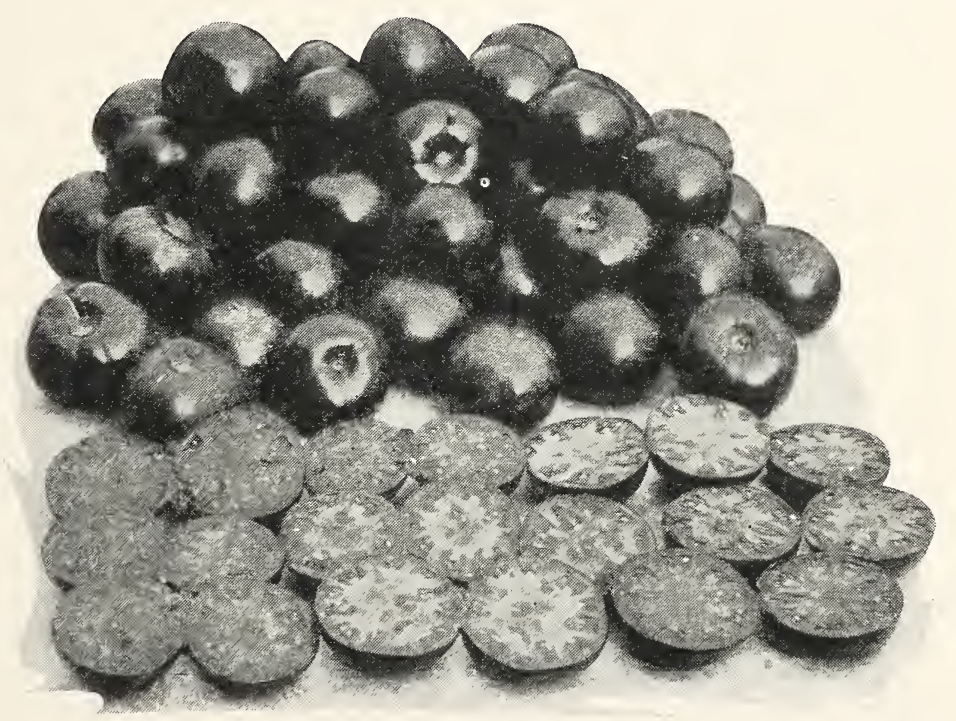

All Fruit for No. 3 Seed Is Hand Cut for Inspection ADIRONDACK EARLIANA 


\section{Experiment Station Bulletins on Tomato Growing}

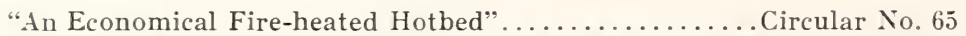
Agricultural Exper. Station, A \& M College, Miss.

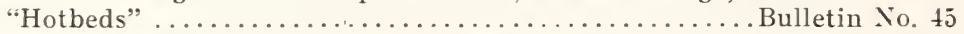

Extension Serrice, Conn. Agri. College, Storrs, Conn.

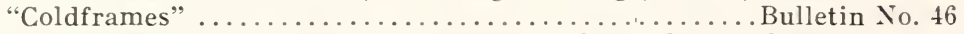

Extension Service, Conn. Agri. College, Storrs, Conn.

"Early Tomato Growing in New Jersey"............... Circular No. 103

Agricultural Exper. Station, New Brunswick, N. J.

"Growing Tomatoes for Early Market"................. Bulletin No. 144 Agricultural Exper. Station, Urbana, Ill.

"Effect of Phosphorus upon the Yield and Time of Maturity of

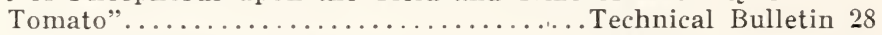
Agricultural Exper. Station, Durham, N. H.

"Growing Tomatoes for the Canning Factory"........... Bulletin No. 96

Extension Service, College of Agri., Ithaca, N. Y.

"Tomatoes As a Truck Crop"................ Farmers Bulletin No. 1338 Bureau of Plant Industry, Washington, D. C.

"Some Experiments with Tomatoes"...................Bulletin No. 218 Agricultural Exper. Station, Lexington, Kiy.

"Preparation of Fresh Tomatoes for Market". . Farmers Bulletin No. 1291 Bureau of Plant Industry, Washington, D. C.

"Tomato Leaf Spot, and Experiments with its Control"..Bulletin No.17i Agricultural Exper. Station, State College, Pa.

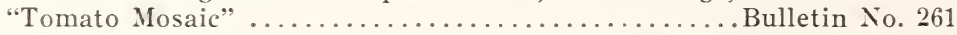
Agricultural Exper. Station, Lafayette, Ind.

"Experiments in Spraying and Dusting Tomatoes"..... Bulletin No. 230 Agricultural Exper. Station, Blacksburg, Va.

"Diseases of the Tomato in Louisiana"................ Bulletin No. 142 Agricultural Exper. Station, Baton Rouge, La.

"Tomato Diseases in Florida"....................... Bulletin No. 185 Agricultural Exper. Station, Gainesville, Fla.

"Tomato Seed Selection"........................... Bulletin No. 173 Agricultural Exper. Station, Bozeman, Mont.

"Selecting and Saving Tomato Seed"..................Bulletin No. 250 Agricultural Exper. Station, Lafayette, Ind.

"Greenhouse Tomatoes"....................Farmers Bulletin No. 1431 Bureau of Plant Industry, Washington, D. C.

"The Pennsylvania Forcing Industry"..........General Bulletin No. 396 Penn. Dept. of Agriculture, Harrisburg, Pa.

"Economic Results in the Pollination of Greenhouse Tomatoes"

Agricultural Exper. Station, Corvallis, Ore.

These up-to-date bulletins, issued free by the stations, cover nearly every phase of tomato growing. Give them a trial on your present problems, and file the list for future reference. 


\section{The Visiting Corner}

The use of nitrate of soda at the field transplanting may seem a dangerous practice to advise, yet it is perfectly safe if correctly done. It has much to commend it.

A plant has to depend, for several days after transplanting, upon the food supply stored up in its own tissues and in the soil directly around the roots. Nitrogen, the element that most promotes growth, is the one usually lacking. The heavy application of water prior to taking up the plants, and the soaking of the root balls in water before taking to the field leave the plant full of water, but with not much food for growth.

A light application of dry nitrate sprinkled over the beds just before the final watering is quickly dissolved by the water and taken up into the plant, giving it a strong reserve of food. The addition of one pound of nitrate to fifty gallons of the water into which the plant roots are dipped will add much food to the earth clinging around the roots. And two pounds of nitrate to fifty gallons of the water applied in the field will place, close around each plant, a supply of available food that will start them growing quickly and surely.

Nitrate of soda is concentrated stuff. If you leave this operation to the hired men instruct them carefully on the following points-and then do it yourself. Apply dry nitrate to the beds only when the plants and leaves are dry; otherwise it may stick on and burn the leaves. Unless the plants are badly checked and need stimulation, use it not more than a day or so before taking up for the field, or they will grow too fast and become soft. While the solution of one pound to fifty gallons of water for dipping and two pounds for field setting may be slightly increased without harm, yet the lesser amounts are enough for best results, and your margin of safety against mistakes is greater. Nitrate is usually prepared for convenient use by dissolving it in enough hot water so that each pound makes a quart of concentrated solution. See that this is put where it cannot accidentally be used full strength; that the amount used for each pail or barrel full of water is correct; and that the water is stirred enough to insure mixing. 
The earlier maturity brought about by the use of acid phosphate seems to be due to the promotion of strong, early growth, with subsequent heavy set of early blossoms. If this is the case, wouldn't it seem advisable to give the seed and plant beds an application of acid phosphate each year, along with the manure compost? Seems like plants should not be obliged to wait till they are set in the field for the phosphorus they need, if much of the benefits of its use are felt prior to blossoming time. This plant bed treatment to supplement a liberal field application, not to take place of it.

Covering the seed bed with burlap or newspaper is a very good policy. It lessens the danger of cooking the seed by a hot sun during the germination period, and keeps the soil moist and soft for the little plants to come up through.

Moisten the soil several hours before you plan to sow or transplant. Shovel over, not hook, all beds which have bottom heat. Seed will germinate best in soil only moist, it will rot if kept too wet. Dry the plants off a few days before transplanting to harden them; wet them down the evening before moving to carry them over without check, and to help the dirt adhere to the roots. Give the young transplants a drink individually before pressing the dirt around the roots; give them another sprinkling early next morning.

$$
* * *
$$

Sixteen pages don't go very far on this subject, do they? We'll hope sometime to have more, for if we can make this little booklet helpful to you we may in this way, as well as in the care given every other operation in the growing and harvesting of your seed, better express our appreciation of your confidence in us.

If we can help in any way, either now or later, please feel free to write us about it. To whatever we know about tomato growing you are most welcome.

And please, along with sending your order in early, writing your name plainly, etc., won't you keep up the practice so many of you have begun - the addition of just a personal note along with the order? It is a very nice habit, we think.

Sincerely yours,

November, 1928.

H. P. LANGDON \& SON.

[ Page Sixteen ] 
. 


$$
\begin{aligned}
& \text { "Not What it Costs- } \\
& \text { What it Does" }
\end{aligned}
$$

